$<$ 原 著 $>$

劇症肝炎患者血㓡による初代分離培養肝細胞のコラーゲン産生

$\begin{array}{llllll}\text { 野口 } & \text { 和典 吉武 正男 } & \text { 古賀郁利子 } & \text { 権藤 } & \text { 和久 } \\ \text { 岩城 義博 釈迦堂 敏 } & \text { 犬塚 貞孝 } & \text { 上野 } & \text { 隆登 } \\ \text { 安倍 弘彦 } & \text { 谷川 久一* } & & & & \end{array}$

要 旨：劇症肝炎患者血浆を含む培養液で, ラット初代分離肝細胞を培養し, 肝細胞によるコ ラーゲン産生について検討した。培養開始後 6 時間以内の早期に肝細胞より連続する線維状構 造物を認めた。この線維は，Mallory-Azan 染色，鍍銀染色にて陽性で，抗ュラーゲン抗体を用 いた蛍光抗体間接法では Type III に陽性であった. 電顕的観察では, 肝細胞内の RER, vesicle は著明に増加して括り，microvilli 起始部の陥凹部にて線維形成像が認められた。線維は，直径 が $120 \mathrm{~nm}$ で明暗帯の格子状周期が明瞭に観察された，線維は，コラゲナーゼ処理にて完全に消 去された. ${ }^{3} \mathrm{H}$-proline の autoradiography では, grain は線維上に認められた. この線維産生は, $10^{-9} \mathrm{~mol}$ 以上のデキサメサゾンの添加で抑制された。上上ことより, 急激で広範な肝細胞障害 時の血中には，肝細胞に対するコラーゲン産生刺激因子が存在すると考克られた。

索引用語： 劇症肝炎患者血浆 初代分離培養肝細胞 コラーゲン コラーゲン産生刺激因子＼cjkstart糖質コルチコイド

はじめに

近年, 肝細胞に collagen prolyl hydroxylase 活性が 存在することが，分離肝細胞を用いて明らかにされ， その後, 初代分離肝細胞もコラーゲン合成を行うこと が報告されてきた西).このことは，肝組織損傷後の修 復過程で, 肝細胞も細胞外基質を産生し, 肝線維化の 進展に重要な役割を果たしている可能性があることを 示唆している。実際に急性障害肝において, 肝細胞も コラーゲンをはじめとする細胞外基質を産生すること が免废電影組織化学法を用いて明らかにされてい $ろ^{5,6)}$. しかしながら, 劇症肝炎のような急速で，かつ 忩範な肝障害時の, 肝細胞の肝ュラーゲン増生に括け る役割についての報告はない。そこで，今回，私共は， ラットより分離した初代肝細胞を，劇症肝炎患者血浆 を用いて培養し，肝細胞によるコラーゲン産生につい て検討を行なった。

\section{材料と方法}

\section{1. 肝細胞の分離扩よび培養}

体重 $200 \mathrm{~g}$ 前後の Wistar 系雄性ラットを, pentbarbital $(0.1 \mathrm{~m} l / 100 \mathrm{~g}$ 体重 $)$ に麻酔し, 滅菌下に開腹し

"久留米大学医学部第 2 内科 <受付日62年 5 月 25 日 $>$
た. 門脈よりカニニーレを挿入し, $\mathrm{Ca}^{2+}, \mathrm{Mg}^{2+}$ free の Hanks 液 $100 \mathrm{~m} l$ で前灌流を行い, 続いて灌流液を $0.05 \% の$ collagenase (Sigma type 1) の Hanks 液に か克た. collagenase 液 5 分間灌流以後は胸部下大静 脈に㨀入したカニューレから流出する液を collagenase 溶液ビンKかえすことにより recirculation system として，約15分間灌流を続けた。灌流後，ラッ トより取り出した肝葴に細切と軽いピペッティングを 加克, pore size が $100 \mu \mathrm{m}, 60 \mu \mathrm{m}, 30 \mu \mathrm{m}$ の mesh で滤 過し, $50 \mathrm{~g} 1$ 分間の遠心洗浄を 3 回行い, 肝細胞を分離 した. この分離肝細胞をインスリン $10^{-8} \mathrm{~mol}$, ペニシリ ソ $\mathrm{G} 100 \mathrm{u} / \mathrm{m} l$, ストレプトマイシン $50 \mathrm{mg} / \mathrm{m} l$, デキサ メサソン $10^{-6} \mathrm{~mol}$ および $10 \%$ 仔牛血清を含む William's medium E (以下 WE と略す) にて細胞数 を $2.5 \times 10^{5} \mathrm{cells} / \mathrm{m} l$ に調整し, plastic culture dish (FALCON 3001, USA) 内で, $5 \% \mathrm{CO}_{2}, 40 \% \mathrm{O}_{2}$ 下, $37^{\circ} \mathrm{C} 24$ 時間培養を行った.

24時間後, monolayer を呈した肝細胞を何も含まな いWE 液で 4 回洗浄後, 10\%劇症肝炎患者血採拉 び, インスリン $10^{-8} \mathrm{~mol}$ を含むWE 液にて培養し経時 的観察を行なった。 また，デキサメサジン $10^{-6} \sim 10^{-11}$ $\mathrm{mol}$, コルヒチン $10^{-5} \mathrm{~mol}$ あるいは, サイトカラシン B $10 \mu \mathrm{g} / \mathrm{m} l$ を添加して影響を観察した。 
Table 1 Summary of cases examined.

\begin{tabular}{l|c|c|c|c|c}
\hline & \multirow{2}{*}{ Cases } & \multirow{2}{*}{ Male : Female } & \multicolumn{2}{|c|}{ Age } & \multirow{2}{*}{ No. Sample } \\
\cline { 4 - 5 } & & & Range & Average & \\
\hline Type A & 2 & $2: 0$ & $38-71$ & 54.3 & 3 \\
Type B & 8 & $5: 3$ & $21-75$ & 37.8 & 21 \\
Type NANB & 2 & $1: 1$ & $32-59$ & 45.5 & 3 \\
\hline
\end{tabular}

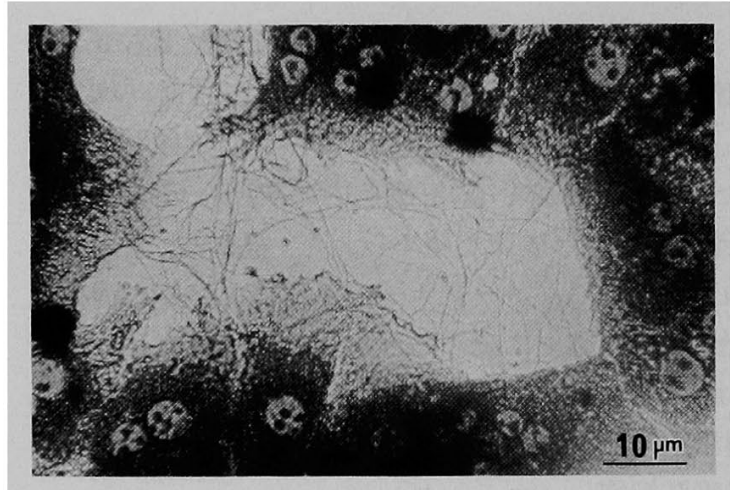

Fig. 1 Light microscopic picture of hepatocytes cultured with the medium containing the plasma from a fulminant hepatitis patient for 6 hours. Fiber formation is observed around hepatocytes.

なお，コントロール群として，10\%健常人血浆，お よびインスリン $10^{-8} \mathrm{~mol}$ を含むWE液にて肝細胞を 培盖し，経時的観察を行なった。

2. 劇症肝炎患者血浆

本実験に用いた血浆は，昭和58年～昭和61年の間に 当院救命救急センターに入院したウイルス性の劇症肝 炎患者12名から採取した，へパリン加血䍝27検体をサ ンプルとした。患者は, 男性 8 名, 女性 4 名で原因は, $\mathrm{A}$ 型 2 名, $\mathrm{B}$ 型 8 名, 非 $\mathrm{A}$ 非 B 型 2 名で, 年龄は 21〜75歳，いずれる劇症肝炎診断基準を満たしていた (Table 1).サンプルは, $-20^{\circ} \mathrm{C} て ゙$ 凍結保存し，使用時

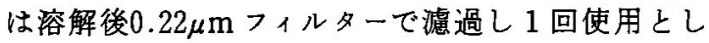
た. また，サンプルをあらかじめ56 $\mathrm{C} 30$ 分間加熱や卜 リプシン，あるいはキモトリプシン処理を行い使用検 討した。

\section{3. 形態的観察方法}

劇症肝炎患者血浆を含む培羡液にて培養された肝細 胞を経時的に光顕で観察するとともに, Mallory-Azan 染色，鍍銀染色括よび抗コラーゲン抗体 Type I, III, IV (ADVANCE Co. Ltd. Japan)を用いた蛍光抗体 間接法にて観察した。

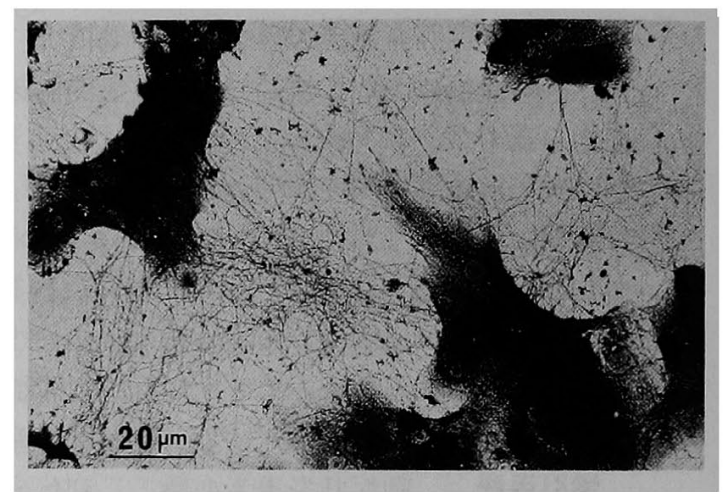

Fig. 2 Light microscopic picture. Fibers produced by hepatocytes are positively stained with Mallory·Azan.

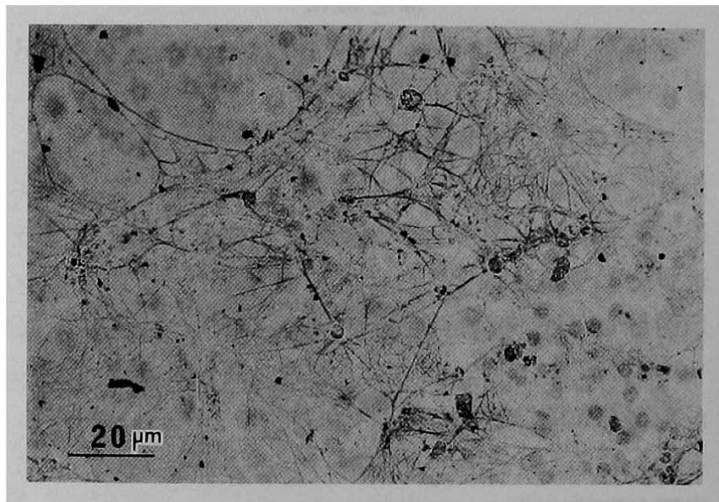

Fig. 3 Light microscopic picture of fibres stained with silver impregnation. Fibers give color reaction in black and brown.

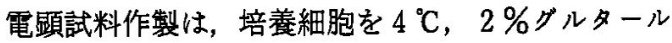
アルデヒド(0.1M Cacodylate buffer, pH 7.4)で40 分固定後, 7.5\%Sucrose 溶液 (同 buffer) で洗浄し， $1 \%$ オスミウム酸（同 buffer）にて 1 時間後固定を行 なった，型のごとくェタノール系列による脱水を行な い，透過電顕試料は培養シャーレにエポンを含むカプ セルを直接立て重合・剥離，超薄切片を作製し，酢酸 ウランと鉛の二重染色を行ない，日本電子 JEM-2000 
EXにて観察した. 走查電顕試料は, 透過型電顕試料と 同様に固定, 脱水の後, 臨界点乾燥, 金蒸着を行ない, 日立 HF-2型走査電子顕徽鏡にて観察した。

さらに，培養肝細胞を ${ }^{3} \mathrm{H}$-proline $4 \mu \mathrm{g} / \mathrm{m} l$ にて 6 時 間あるいは, 12時間 incubation $し$, 光顕, 電䫓オート ラジオ゙ラフィーを行なった.

実験中出現する線維のコラゲナーゼ感受性を検討す るため,トリプシンインヒビターを含む0.1または
0.01\%コラゲナーゼ（Sigma， type 1) 溶液で incubationして観察した。

\section{実験結果}

初代培養肝細胞を劇症肝炎患者血浆 $10 \%$ を含さ WE で培羡し，経時的に観察すると 4 〜 時間，遅くとも 12時間以内に細胞表面あるいは，細胞と連続して細胞 間吵に線維状構造物が網状または，束状に観察された (Fig. 1).この線維は, Mallory-Azan 染色では濃青色

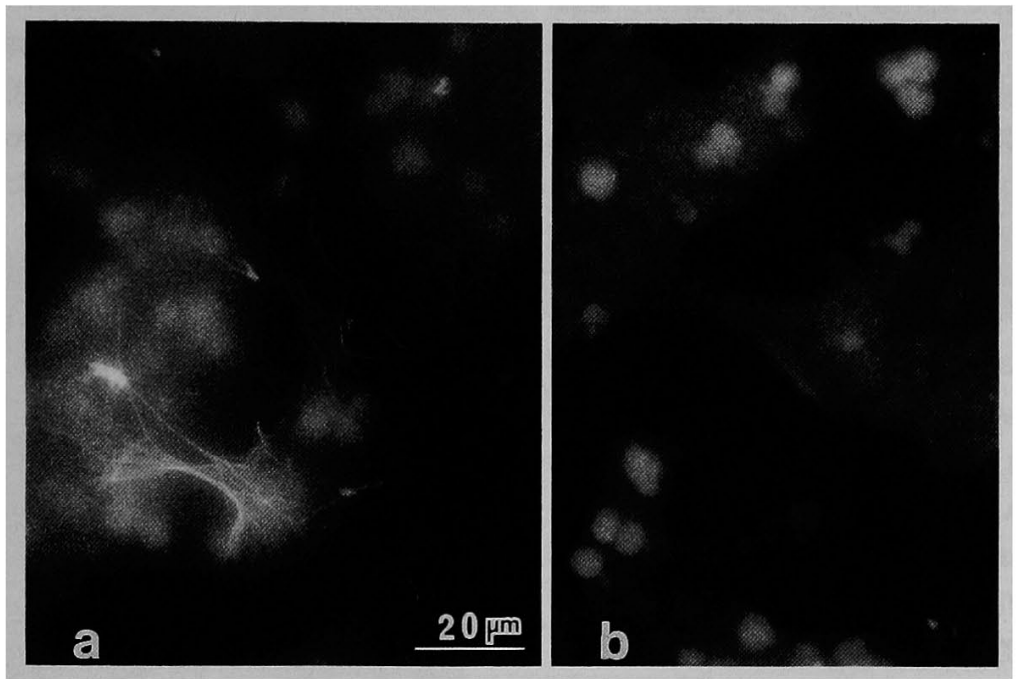

Fig. 4 Light microscopic pictures. Indirect immunofluorescence method by using anti-collagen type III antibodies. (a): A bundle of fivers appears positive. (b) : Control.
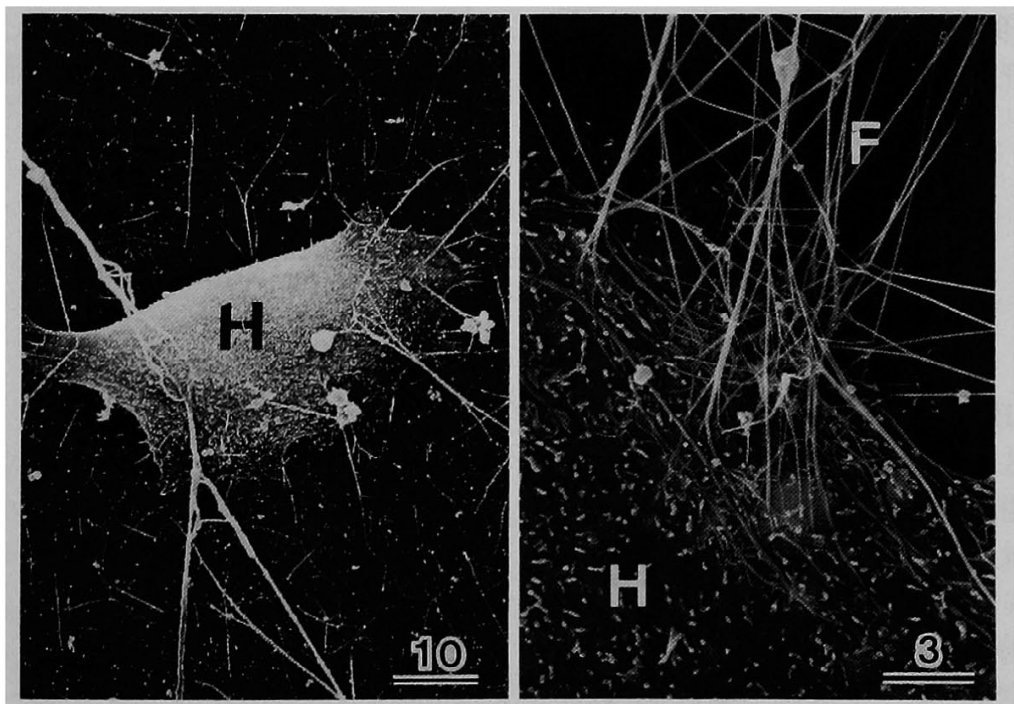

Fig. 5 Scanning electron micrographs. Fibers seem to be produced on the surface of the cultured hepatocyte. $\mathrm{H}$ : hepatocyte, $\mathrm{F}$ : fiber 
に，鍍銀染色では暗灰色一黒色に染色された（Fig. 2， 3).48時間までの実験では，抗コラーゲン抗体を用い た営光抗体間接法では, type III のみ陽性であった (Fig. 4). 走查型電子顕钽鏡にて観察すると, 線維は培 養肝細胞の細胞膜より出現しており，この出現領域は 比較的集静傾向が認められた（Fig. 5)，透過型電子顕 鏡では, 培㕌肝細胞内の RER p vesicle が著明に増 加しているのが観察され，microvilli 起始部の陥凹部 にて線維が形成される像が認められた (Fig. 6). 線維 は直径が119.6士6.3nm (Mean士SD) で細胞より遠位 部になるに従って明暗帯の格子状周期が明瞭に観察さ れた (Fig. 7)。複数の線維が束状をなしている部位で は，隣接した線維の明暗帯は同位相を呈していた(Fig.

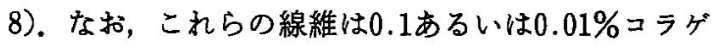
ナーゼ処理にて短時間のらちに完全に消去された。線 維の性状を Table 2 に示す。 ${ }^{3} \mathrm{H}$-proline を用いたオー トラジオグラフィーでは, 光顕的には grain は細胞内 および線維上に認められ，電頭的には細胞内の RER, vesicleおよび線維上に観察された（Fig. 9).

健常人血将を用いて肝細胞を培着したコントロール 群では，肝細胞による線維産生は観察されず，細胞内 小器官の有意な変化も認められなかった。

次に, 培養肝細胞からの線維出現の培養条件を検討 すると, 通常の初代分離肝細胞培養で用いるデキサメ サゾン濃度の $10^{-6} \mathrm{~mol}$ では出現せず, $10^{-10} \mathrm{~mol}$ 以下の 濃度で出現した. コルヒチン $10^{-5} \mathrm{~mol}$ では全く現れず, サイトカラシン B $10 \mu \mathrm{g} / \mathrm{m} l$ では時間的にやや達れて 出現した。線維出現の培養条件を Table 3 に示す。

いっぽう，劇症肝炎患者血浆側の条件を検討すると，
血㫽をあらかじめ加熱処理あるいはトリプシン処理を 行なったサンプルでは全く出現しなかったが，キモト リプシン処理では抑制されなかった（Table 4).

今回用いたサンブルのうち, 培養肝細胞と incubation $し$, 線維が 6 時間以内に多量に出現したすのを陽 性, 少量出現あるいは12時間以内に出現したものを弱 陽性，48時間まで出現しなかったものを陰性として検 討すると，陽性10（37\%)，弱陽性 $4(15 \%)$, 陰性 13 (48\%) であった (Table 5). 肝炎発症起因別では, A， B，非 A 非 B の type 間に有意差はなく，サンプル 採取時の患者の T.B., Albumin, GOT, GPT, LDH, $\gamma$-gl との間にも明らかな相関は誌められなかった。 た だし，陽性あるいは弱陽性を示したサンプル採取時の

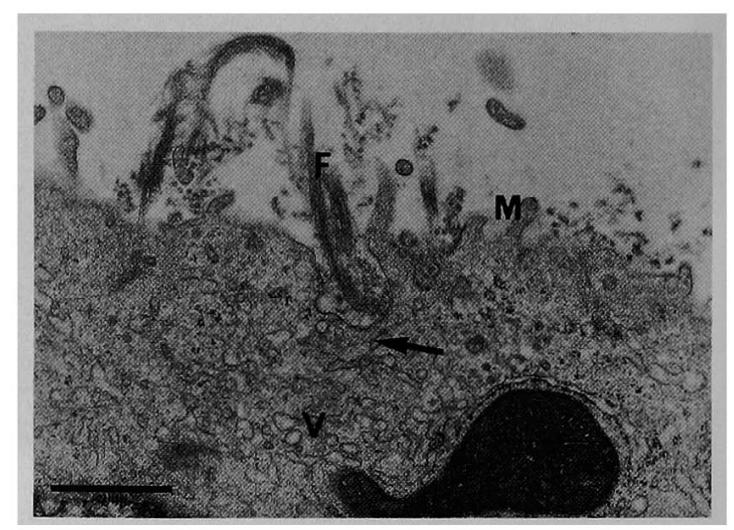

Fig. 6 Transmission electron micrograph. Fiber seems to be formed in the pit of the plasma membrane of the hepatocyte. Many vesicles are observed in the cytoplasm. $\mathrm{F}$ : fiber,

Table 2 Characteristics of fibers produced by the primary cultured hepatocytes.

\begin{tabular}{l|l}
\hline Diameter & $\begin{array}{l}119.6 \pm 6.3 \mathrm{~nm}(\mathrm{M} \pm \mathrm{SD}) \\
\text { Cross-striation }\end{array}$ \\
$\begin{array}{l}(+) \\
\text { low density band }\end{array}$ \\
$\quad \begin{array}{c}5 \mathrm{~nm} \\
\text { high density band }\end{array}$ \\
$\begin{array}{l}\text { Mallory-Azan staining } \\
\text { positive }\end{array}$ \\
$\begin{array}{l}\text { Silver impregnation staining } \\
\text { Indirect immunofluorescence method }\end{array}$ & positive \\
$\quad$ anti-type I collagen antibodies & negative \\
anti-type III collagen antibodies & positive \\
$\quad$ anti-type IV collagen antibodies & negative \\
Sensitivity to collagenase & \\
treatment by $0.01 \%$ collagenase* & disappeared within 1 hour \\
treatment by $0.1 \%$ collagenase* & disappeared within 10 minutes \\
\hline
\end{tabular}

*trypsin inhibitor was added 

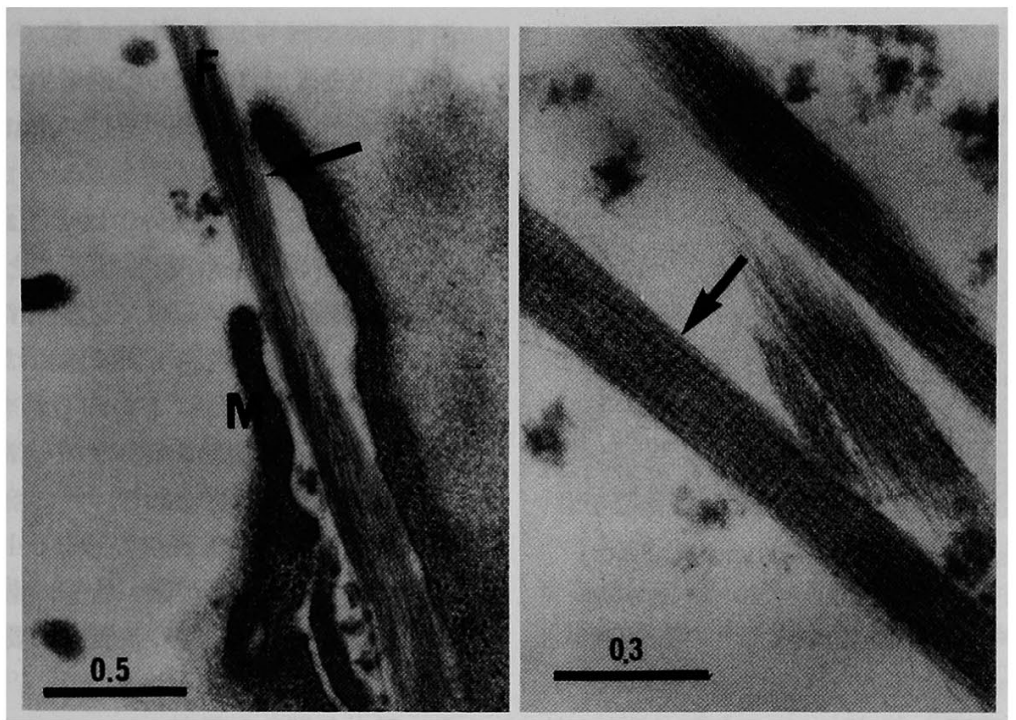

Fig. 7 Transmission electron micrographs. The fiber shows to have typical cross-striation with a diameter of $120 \mathrm{~nm}$. F: Fiber, $\leftarrow$ : cross-striation, $\mathrm{M}:$ microvilli.

Table 3 Dexamethasone and cholchicine show to suppress a collagen formation of cultured hepatocytes.

\begin{tabular}{|c|c|c|}
\hline \multicolumn{2}{|c|}{ Culture medium } & \multirow{2}{*}{$\begin{array}{l}\text { Collagen production } \\
\text { by cultured hepatocyte }\end{array}$} \\
\hline & Additional substance & \\
\hline $\begin{array}{l}\text { William's medium E } \\
\text { L-proline } 30 \mathrm{mg} / l \\
\text { et al. } \\
\text { Insulin } \quad 10^{-8} \mathrm{~mol} \\
\text { Plasma from the patient } \\
\text { with fulminant hepatitis } \\
(10 \%)\end{array}$ & $\begin{array}{cc}\text { Dexamethasone } \\
10^{-6} & \mathrm{~mol} \\
10^{-7} & \mathrm{~mol} \\
10^{-8} & \mathrm{~mol} \\
10^{-9} & \mathrm{~mol} \\
10^{-10} & \mathrm{~mol} \\
10^{-11} & \mathrm{~mol} \\
\text { Colchicine } & \\
10^{-5} & \mathrm{~mol} \\
\text { Cytochalasin } & \\
10 & \mu \mathrm{g} / \mathrm{m} l\end{array}$ & $\begin{array}{c}(-) \\
(-) \\
(-) \sim( \pm) \\
( \pm) \sim(t) \\
(t) \\
(+) \\
(-) \\
( \pm) \sim(+) \\
\text { delayed }\end{array}$ \\
\hline
\end{tabular}

Table 4 Properties of fibrogenic factor to the hepatocyte in the plasma from patients with fulminant hepatitis.

\begin{tabular}{l|c}
\hline \multicolumn{1}{c|}{ Treatment } & Inactivation \\
\hline Heat $\left(56^{\circ} \mathrm{C}, 30\right.$ minutes $)$ & $(+)$ \\
Trypsin & $(+)$ \\
Chymotrypsin & $(-)$ \\
Freezing $\left(-20^{\circ} \mathrm{C}\right)$ & $(-)$ \\
\hline
\end{tabular}

患者はすべて Hepaplastin test (HPT) が10\%以下で あった．血装交換との関係をみると，施行前陽性だっ た 6 例は施行後, 弱陽性 1 例, 陰性 5 例に転じた。し かし, 弱陽性たっった 2 例は施行後, 共に再び陽性となっ た. いっぽう, 施行前陰性だった 7 例は陽珄 1 例, 弱 陽性 2 例, 陰性 4 例に転じた。 予後との明らかな相関 は認められなかったが，入院時陽性でその後陰性とな り生存した例と，入院時より陰性で死亡前日強陽性に 転じた各 1 例が存在した。 


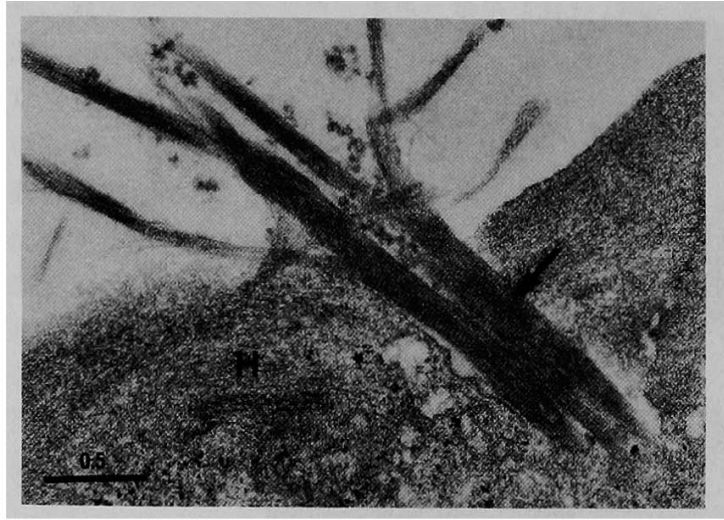

Fig. 8 Transmission electron micrograph. Fihers produced by a hepatocyte show to have same phase of cross-striation. $\mathbf{H}$ : hepatocyte, $\leftarrow$ : crossstriation

\section{考察}

重症肝炎後には，肝の線維増生が高まることが知ら れているが，これには，一般に Fat storing cells (Ito cells）が重要な働きしている5,7)。しかしながら，肝 細胞内にコラーゲン合成の key enzyme の一つである prolyl hydroxilase が存在することより，特殊な条件 下では肝細胞もこラーゲンを産生する可能性がある. いっぽう，劇症肝炎患者血液中には，肝細胞に対する 増殖因子が存在することが知られている 肝細胞は，成熟細胞でありながら堌殖因子により自己 堌殖することが可能であり，かつ培美液中にプロリン を必要とする9). 分離直後の cell-cell contact を有しな い肝細胞は，分化度が低い状態にあると考学られ，分 化するには特定の細胞外基質が必要であることが示さ

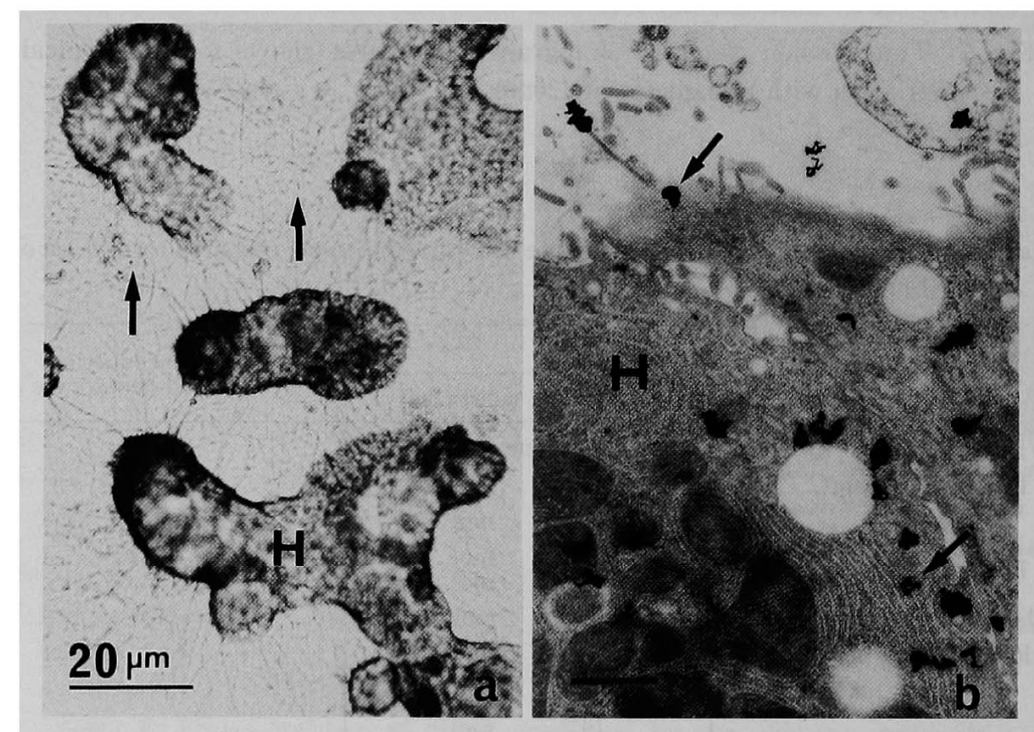

Fig. 9 Light and electron microscopic autoradiographs. Grains of ${ }^{3} \mathrm{H}$-proline are distributed on the fibers and the rough endoplasmic reticulm of the hepatocyte. $\mathrm{H}$ : hepatocyte, $\leftarrow:{ }^{3} \mathrm{H}$-proline grain, (a): Light micrograph, (b) : Electron micrograph.

Table 5 Fiber production by primary cultured hepatocytes incubated with the medium containing $10 \%$ plasma from patients with fulminant hepatitis.

\begin{tabular}{|c|c|c|c|}
\hline Fiber formation & No. sample (\%) & Total sample & No. patient \\
\hline $\begin{array}{l}+ \\
\pm \\
-\end{array}$ & $\left.\begin{array}{c}10(37 \%) \\
4(15 \%) \\
13(48 \%)\end{array}\right\}(52 \%)$ & 27 samples & 12 patients \\
\hline
\end{tabular}

$(+)$ Fiber formation appeared within 6 hours

(士) Fiber formation appeared a small amount or within 12 hours

(-) Fiber formation was not observed within 48 hours 
れている(0).これらのことから，急激な肝細胞脱落を伴 ら劇症肝炎において cell-cell contactをなくした肝細 胞は、コラーゲンなどの細胞外基質を産生するととも に，増殖，分化を行い小葉構築の維持拈よび，補充機 構といら生体防御反応を示す可能性がある.

今回の実験において，劇症肝炎患者血浆で培養した 肝細胞より出現した線維は，光顕および電顕による形 態的観察の結果より培盖肝細胞より産生された線維と 考えられた．この線維は、コラゲナーゼにて短時間で 消去され，直径約 $120 \mathrm{~nm}$ で特徽的な明暗帯を有する格

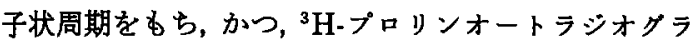
フィーの結果よりコラーゲン線維と考えられた．生体 内でコラーゲン線維の走行が平行に並心゙場合には，各 線維は隣接する線維と横紋の位相をそろえて並ぶこと が知られているが11)，Fig. 8 亿示すごとく，同一部位 で産生される複数のコラーゲン線維は, 同じ位相の格 子状周期をすつるのと考劣られた。またこの線維は 抗コラーゲン抗体を用いた蛍光抗体間接法では, type III のみ陽性であったことより， type III コラーゲンと 推測され，Mallory-Azan 染色より鍍銀染色のほうが より典型的に染色された結果とも一致した。しかしな がら，この線維は生体内で観察される type III コラー ゲン線維に比べ径が大きく，格子状周期も短かった。 生体内でのコラーゲン線維は，長軸方向への力による 伸展にて格子状周期や直径が变化することが知られて おり11，今回の実験で認められたコラーゲン線維の形 態学的特徵は, 細胞に上る王迫や伸展力が加わらない 培羞下といら特殊条件を反映したすのと思われる。

培坫肝細胞からのこのュラーゲン線維出現時間をみ ると，最も早いもので約 3 時間であり陽性群はほとん ど 4〜6時間であった，この時間は，増殖因子により 肝細胞が分裂増殖のため必要とする時間上りる短く， 少なくとも分裂増殖以前にコラーゲンを産生放出して いると考えられる、コラーゲン産生細胞でのプロリン の取り込みは極めて迅速で，プロコラーゲンの細胞内

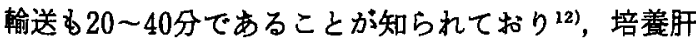
細胞内に括いても比較的短時間でプロコラーダンの産 生, 輸送が可能なるのと推測される。プロコラーゲン の細胞内輸送に関しては, microtubules が重要な働き をしていることが報告されているが13，本実験におい て anti-microtubular drug であるコルヒチンにて線 維出現が全く認められなかったことより，同様の機序 が示唆された. microfilament のプロコラーゲン輸送 に関しての報告は極めて少ないが，今回のサイトカラ
シン B 添加濃度では microfilament は，活とんど影響 していないと考えられる.糖質コルチコイドは, prolyl hydroxylase をはじめとする細胞内でのプロコラーゲ ン分子の修飾を行なう 4 種の酵素すべての活性を低下 させ，特異的にコラーダンタンパクの合成を减少させ ることが知られている14,15)．今回の実験でも培盖液中 のデキサメサゾン濃度は, $10^{-10} \mathrm{~mol}$ 以下でなければ十 分なコラーゲンの産生は認められなかった。この結果 は, Guzelian らのデキサメサゾンは培養肝細胞のコ

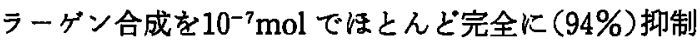
し，50\%抑制濃度は $10^{-9} \mathrm{~mol}$ であるといら報告とよく 一致している(16). 以上のことより，今回の実験において 培養肝細胞にコラーゲンタンパクの合成，輸送，分泌 といら一連のコラーゲン産生過程が存在すると考えら れ，しかも，特定の患者血浆中に prolyl hydroxylase をはじめとするコラーゲン合成䤃素活性を促進させる 因子が存在するものと考党られる。この因子は, $56^{\circ} \mathrm{C} 30$ 分加熱，あるいはトリプシン処理にて不活化されるが， キモトリプシン処理では不活化されなかった，この結 果は，中野らが報告している fibroblast に対するリン 八球由来の fibro genic factorの性状と極めて類似し て扔り ${ }^{17)}$, 肝細胞のコラーダン合成も結果的に cytokine により調節されている可能性があり今後検討が 必要である.

臨床での検查結果と対比すると, 劇症肝炎患者血浆 でも陽性，弱陽性あるいは全く陰性を示すものが存在 した。この結果は，先に述べた因子の量が関係してい るのか，あるいは糖質コルチコイドなどの抑制因子が 関与しているかは現時点では不明である。しかしなが ら，少なくとも，この肝細胞に対するコラーゲン産生 刺激因子は，HPT が10\%以下でなければ出現しない ことより，急速で，から激しい肝細胞壊死が起きた状 況下で出現するすのと推測される。さらに，血采交換 施行にて陽性だった 6 例のらち 5 例が陰性に転じたこ とより，血变換にてこの肝細胞にコラーゲンを産生 させる因子は，除去，あるいは減弱される可能性すあ ると考克られる。.この因子と予後の関係は，現時点で 明らかではなかったが，入院時陽性でその後血浆交換 等の治療により陰性に転じ生存した例と，入院時より 陰性で死亡前日に強陽性に転じた症例が存在したこと は興味深く，今後症例を重就るととに，さらに因子 の性状と由来を検討する必要があると思われた。

今回の実験は，初代分離培盖肝細胞も条件がそろ之 ばララーゲン合成が短時間にて可能であることを示す 
とともに，臨床的に肝線維化に対する効果的な治療法 がない今日，肝線維化の機序と，抑制あるいは促進因 子に関して研究するのに有効なモデルと考えられた。

\section{結論}

（1）初代分離培養肝細胞を，劇症肝炎患者血浆儿て 培養し，肝細胞によるコラーゲンの産生を認めた。

（2）初代分離培養肝細胞によるコラーゲンの産生 は, $10^{-9} \mathrm{~mol}$ 以上のデキサメサゾン存在下では抑制さ れた。

（3）劇症肝炎患者血浆中には，肝細胞に対するコ ラーゲン産生刺激因子が存在すると考光られ，この因 子は56采30分加熱, トリプシン処理にて不活化された が，キモトリプシン処理では不活化されなかった。

（4）肝細胞に対するコラーゲン産生刺激因子は，急 速で，かつ激しい肝細胞壊死が扣こった状況下で出現 するものと推測された。

（5）以上のことより，急速で広範な肝細胞障害時に は残存肝細胞もコラーゲンを産生し, 肝の線維増生に 関与している可能性が示唆された。

この要旨の一部は，第72回日本消化器病学会総会におい て発表した。

なお，本研究に際し御協力いただいた研究補助員の保田 由美子, 军田口稔子, 大城恭子, 松崎寿子, 電子頭㪍鏡公の 北原，東両技師に深謝いたします。

\section{文献}

1) Ohuchi $K$, Tsurufuji $S$ : Protocollagen prolyl hydroxylase in isolated rat liver cells. Biochem Biophys Acta 258: 731-740, 1972

2) Philip S, Guzelian G, Dastiger Q, et al : Collagen synthesis by the hepatocyte. Studies in primary cultures of parenchymal cells from adult rat liver. Cell Res 1: 83-93, 1981

3) Hata R, Ninomiya $Y$, Sano J, et al : Activation of collagen synthesis in primary culture of rat liver parechymal cells. J Cell Phys 122 : 333 $-342,1985$

4) Diegelmann FR: Synthesis of extracellular matrix components by cultured hepatocytes. In: Research in isolated and cultured hepatocyte, Edited by A Guillouzo and C GuguenGuillouzo, John Libbey Eurotext, London, Paris, 1986, p209-224

5）上野隆登，犬塚貞孝，谷川久一，他：急性障害肝の 細胞外基質に関する兔度組織学的梌討. 肝喊
$28: 1589-1596,1987$

6) Clement B, Grimaud JA, Campion JP, et al : Cell type involved in collagen and fibronectin production in normal and fibrotic human liver. Hepatology 6 : 225-234, 1986

7) Tanikawa K: Ultrastructure of hepatic fibrosis. In: Collagen metabolism in the liver, Edited by H Popper, K Becker. Stratton intercontinental Medical Book Corp, 1975

8) Nakayama $H$, Tsubouchi $H$, Gohda $E$, et al : Stimulation of DNA synthesis in adult rat hepatocytes in primary culture by sera from patients with fulminant hepatic failure. Biomedical Research 6:231-237, 1985

9) Ichihara $A$, Nakamura $T$, Noda $C$, et al: Control of enzyme expression deduced from studies on primary cultures of hepatocytes. In : Research in isolated and cultured hepatocytes, Edited by A Guillouzo and C Guguen-Guillouzo, Jhon Libbey Eurotext, London, Paris, 1986, p187 $-207$

10) Reid ML, Narita M, Fujita M, et al : Matrix and hormonal regulation of differentiation in liver cultures. In : Reseach in isolated and cultured hepatocytes, Edited by A guillouzo and $\mathrm{C}$ Guguen-Guillouzo, Jhon Libbey Eurotext, London, Paris, 1986, p225-258

11）梶川欽一郎：膠原線維の超煞細構造. 肝胆膵 3 ： 455-462, 1981

12) Bornstein $P$ : The biosynthesis, secretion and processing of procollagen. In : Biology of collagen, Edited by A Viidik and J Vuust, Academic Press, 1980, p62-76

13) Ehrlich HP, Rose R, Bornstein P: Effect of antimicrotubular agents on the secretion of collagen. A biochemical and morphological study. J Cell Biol 62 : 390-405, 1974

14) Risteli J : Effect of predonisolone on the activities of the intracellular enzymes of collagen biosynthesis in rat liver and skin. Biochem Pharmacol 26: 1265-1298, 1977

15) Oikarinen A: Effect of cortisol acetate on collagen biosynthesis on the activities of prolyl hydroxylase, lysyl hydroxylase, collagen galactosyl transferase and collagen glucosyl transferase in chick-enbryo tendon cells. Bio- 
chem J 164 : 533-539, 1977

16) Guzelian SP, Lindblad JW, Diegelman FR, et al: Glucocorticoids suppress formation of collagen by the hepatocyte. Studies in primary monolayer cultures of parenchymal cells pre- pared from adult rat liver. Gastroenterology $86: 897-904,1984$

17）中野 博, 宮村正男, 河原佰久, 他：線維化調節要

因. 最新医学 $38: 1151-1157,1983$

\title{
Collagen biosynthesis of primary cultured hepatocytes with plasma from patients with fulminant hepatitis
}

\author{
Kazunori Noguchi, Masao Yoshitake, Yuriko Koga, Kazuhisa Gondo, \\ Yoshihiro IwakI, Satoshi SHakado, Sadataka InUzUKa, \\ Takato UENo, Hirohiko ABE and Kyuichi TANIKaWA*
}

The present study aimed to elucidate the presence of fibrogenic factor to the hepatocyte in the plasma of fulminant hepatitis patients and to evaluate the role of hepatocytes on the hepatic fibrosis by using primary cultured hepatocytes of rat. The isolated hepatocytes were cultured with William's medium E containing $10 \%$ plasma from the patient with fulminant hepatitis. Fiber formation was obserbed around the hepatocyte in as little as 6 hours and gradually increased in amount by light and electron microscopic observations. These fiber showed to have typical cross-striation in diameter of $120 \mathrm{~nm}$ and were stained with Mallory-Azan, silver impregnation and anti type III collagen antibodies. ${ }^{3} \mathrm{H}$-proline grains were distributed on the fibers and the rough endoplasmic reticulm of the hepatocyte by autoradiographic study. It is suggested that the fibrogenic factor accelerating the hepatocyte to synthesize collagen is present in the plasma from patients with fulminant hepatitis.

* The Second Department of Internal Medicine, School of Medicine, Kurume University (Kurume) 